\title{
Weed Seed Inhibition under Solarization Treatment with Different Mulch Color in Tropical Highland Organic Farming System
}

\author{
Nanik Setyowati ${ }^{\#}$, Uswatun Nurjanah ${ }^{\#}$,Zainal Muktamar*, Fahrurrozi ${ }^{\#}$, Sigit Sudjatmiko ${ }^{\#}$, \\ Mohammad Chozin ${ }^{\#}$

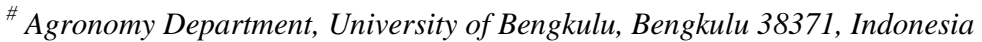 \\ E-mail:nanik_srg@yahoo.com; uswatun.nurjannah@gmail.com; rozi38125@yahoo.com; s1g1t_s@yahoo.com; m_chozin@hotmail.com
}

*Soil Science Department, University of Bengkulu, Bengkulu 38371, Indonesia

E-mail:muktamar1959@yahoo.com

\begin{abstract}
Weeds are the major problem in organic crop production. Soil solarization is a method using clear plastic films to increase soil temperature to control pest organisms such as fungi, bacteria, and weed seeds. The study aimed to evaluate the effect of different plastic mulch color on weed seed inhibition. The experiment was carried out in CAPS Research Station located in Air Duku Village, Bengkulu, Indonesia at $1054 \mathrm{~m}$ above sea level, arranged in Randomized Completely Block Design with 3 replications. Treatments comprised 4 different colors of plastic films, i.e silver-black, black, clear, and red as well as control (without mulch). Plastic mulch was laid on $1 \mathrm{~m}$ wide $\times 2 \mathrm{~m}$ long raised soil bed for four weeks from April 20-May 23, 2016. Soil temperature underneath plastic mulch at depth of 5, 10, 15, $20 \mathrm{~cm}$ from the surface were measured daily at noon. After incubation, soil sample was collected from 0-5; $5-10 ; 10-15 ; 15-20 \mathrm{~cm}$ depths. Weed seed germination of each soil sample was tested in the greenhouse. A number of weeds were observed after four weeks. The experiment indicated that a month of soil solarization using clear plastic mulch resulted in greatest soil temperature, increasing by $\mathbf{0 . 5 4 - 1 . 8 4 \%}$ as compared to control. Treatment of plastic mulches was effective to suppress seed inhibition at the soil depth of $\mathbf{0 - 1 5} \mathrm{cm}$, as indicated by numbers of germinated weed and its dry matter. Longer soil solarization is necessary to obtain the highest reduction of weed growth in the tropical highland organic farming system.
\end{abstract}

Keywords - weed; plastic mulch; organic farming system; tropical highland; solarization.

\section{INTRODUCTION}

Organic farming takes benefit for its nutrient availability mainly from organic fertilizers. Organic fertilization is reported to improve soil quality and increases crop performance [1]-[5]. Along with the release of plant nutrients, application of such fertilizer often also carries a lot of weed seed species. A study by [6], revealed that soil fertilized with cattle manure had higher number weed species than that of without fertilization. In addition, some weed species produce hundreds even thousands of seeds in a single plant. Commelina nudiflora produces 311 seeds per plant while Amaranthus gracilis and Cyperus difformis are able to generate 9.450 and 21.096 seeds per plant, respectively, leading to soil seed bank. Numbers of weed seed in agricultural soil is approximately $34.000-75.000$ seeds per $\mathrm{m}^{2}$ [7]. Germination of carrying over weed seeds from manure together with other weed outspread brings about the serious problem in organic farming practices; principally due to that weed control using synthetic herbicide is strictly prohibited. To date, effective herbicide to control weeds in the organic farming system has not been available. Soil solarization is a reliable solution to control weed for crop production in the organic farming system since soil solarization is able to suppress numbers of weeds in soil. Soil solarization involves disinfestations using passive solar heating of moist soil covered with mulch. Inactivation of soil borne pathogens and pest from direct thermal is the most important mechanism in soil solarization process. This physical mechanism causes soil temperature to increase where many pathogens and pests are lethal [8]. However, temperature requirement for weed seed thermal death might vary. Black nightshade, common purslane, and tumble pigweed are more persistent than barnyard grass, London rocket, and annual sowthistle, although temperatures of 50 ${ }^{\circ} \mathrm{C}$ and above are deadly to seeds of all species.[9]

Numbers of researcher have reported that soil solarization is an effective method to control weed mainly in tropical agriculture area with high daily temperature. The previous study conducted by [10] pointed out that organic mulch as 
well as polyethylene was able to increase soil temperature. Transparent plastic mulch had significantly higher soil temperature than that of black plastic mulch. Greatest soil temperature was obtained in soil surface and the temperature was lower as soil depth increased. Soil solarization treatment had caused soil temperature to rise up to $42^{\circ} \mathrm{C}-55^{\circ} \mathrm{C}$ at the depth of $5 \mathrm{~cm}$; then lower to $32^{\circ} \mathrm{C}-37^{\circ} \mathrm{C}$ at $45 \mathrm{~cm}$ from the soil surface. Another study pointed out that soil solarization suppressed weed growth and expansion of pest and diseases, as well as increased crop yield [11]-[13].

Duration of solarization and mulch thickness are among factors influencing the effectiveness to control weeds. An experiment conducted by [14] indicated that reduction of weed density and biomass was observed when the period of solarization increased. Solarization for 4-6 weeks is necessary to reach the high temperature to suppress weed growth and development [11] [15]. A study in Syria noted that 46 out of 57 weed species was suppressed after 50 days of mulch treatment. Soil solarization for 45 days was reported to suppress weed growth up to $80 \%$ [16]. Polyethylene thickness of 100 microns had higher weed density and biomass than that of 200 microns [14]

Soil solarization to suppress weed growth is only effective at surface soil, but not at subsoil, mainly annual weeds and those with hard seeds. Soil solarization leads surface soil temperature to reach $38-50^{\circ} \mathrm{C}$ at $10-20 \mathrm{~cm}$ depth [17]. Other experiments indicated that in comparison to control, mulch raised soil temperature by $3-6^{\circ} \mathrm{C}[16]$, by $2.2-3.4^{\circ} \mathrm{C}[13]$, by $2.21^{\circ} \mathrm{C}$ on Vertisols [18].

Mulch also increases soil moisture content along with the increase in soil temperature. Soil moisture content increases by $21.1 \%, 20.4 \%$, and $19.2 \%$ when soil is treated with clear plastic mulch, black plastic mulch, and blue plastic mulch, respectively [18].

Soil solarization is able to inhibit weed growth up to 50$93 \%$, leading to higher crop yield as compared to control [19]. Solarization treatment increased the yield of tomato [20] and carrot [21].

The result of soil solarization experiment is often not consistent. Research conducted by [22] resulted that only were black and silver mulches effective to reduce weed growth while clear, blue and red mulches stimulated the growth of weed. This might be associated with soil surface environment to sustain weed growth. A similar result was reported by [23] that clear and blue mulches increased weed population. Research on soil solarization under the organic farming system is very limited and control of weed in this system is necessary to prevent reduction of crop production. The study aimed to evaluate the effect of different plastic mulch color on weed seed inhibition.

\section{MATERIALS AND METHODS}

\section{A. Initial Weed Identification}

Weed species were identified using a method described by [24]. The area required for the experiment was assigned and separated into 3 blocks. Weed species at each block was identified and sampled twice. Identification showed that weed species in the area was relatively homogeny; therefore, the experimental block was separated based on land slope.
Dominant initial weed species were Ageratum houstonianum and Leersia hexandra.

\section{B. Experimental Site and Amendment}

The experiment was carried out at Closed Agriculture Production System (CAPS) Research Station located in Air Duku Village, Sub-District of Selupu Rejang, Rejang Lebong District, Bengkulu Province, Indonesia at $1054 \mathrm{~m}$ above sea level. The area is positioned at a longitude between $102^{\circ} 36^{\prime} 54.96 " \mathrm{E}$ and $102^{\circ} 36^{\prime} 56.82^{\prime \prime} \mathrm{E}$ and a latitude between $3^{\circ} 27^{\prime} 34.26$ " S and $3^{\circ} 27^{\prime} 37.02$ " S. Soil was classified as an Andepts with sandy loam textural classification. The experimental site was cropped to organic vegetables since 2009. Each season, the land was fertilized with organic fertilizer, i.e. dairy cattle manure compost or vermicompost at the rate of $15 \mathrm{Mg} \mathrm{ha}^{-1}$. Dairy cattle manure compost and Vermicompost were produced by CAPS Research Station. No synthetic fertilizer and herbicide were applied to the soil for the last 7 years. Weed control was manually carried out each season by reversing soil and accumulating the weed for compost.

\section{Experimental Design and Treatment}

The experiment was arranged in Randomized Completely Block Design with 3 replications. Treatment consisted of 4 different colors of plastic mulches, i.e. silver black, black, clear, and red as well as control (without mulch).

Before soil bed construction, the land was cleared of weeds and the area required for the experiment was measured. Forty-two $1 \mathrm{~m}$ x $2 \mathrm{~m}$ soil beds were constructed on 19 April 2016. Soil bed was separated by $50 \mathrm{~cm}$ within the block and $100 \mathrm{~cm}$ between block. Each different color of mulch was laid out in soil bed, securing with bamboo nails at each side and corner of soil bed. The mulch was allowed to stand for one month from 20 April 2016 to 23 May 2016. Soil temperature underneath plastic mulch at depth of 5, 10, $15,20 \mathrm{~cm}$ from the surface were measured daily at noon.

After incubation, the soil sample was collected at depth of $0-5,5-10,10-15$, and $15-20 \mathrm{~cm}$. Approximately $2 \mathrm{~kg}$ of soil was sampled using small shovel starting from deepest layer to avoid soil contamination from shallower depth. Weed seed germination was tested in the greenhouse. The soil sample was spread out in the tray for weed germination. The soil was kept moist by watering when required. Number and dry weight of weed was observed after four weeks of incubation

\section{Statistical Analysis}

Statistical analysis was carried out using PROC GLM in Statistical Analysis System version 9.13. portable at probability $<0,05$. Treatment mean was separated using Duncan Multiple Range Test at the probability level of $5 \%$.

\section{RESULTS AND DISCUSSION}

Figure 1 shows that soil solarization using clear plastic mulch exhibited highest soil temperature at all depth but at the depth of $0-5 \mathrm{~cm}$ where the red plastic mulch was slightly but not significantly higher. This result coincided with that concluded by [25], where transparent plastic mulch increased soil temperature up to $43^{\circ} \mathrm{C}$. This might be associated with the characteristics of clear plastic mulch 
where more light radiation goes through the clear plastic and deeper to the soil profile.

Clear plastic mulch raised soil temperature by $0.54-$ $1.84^{\circ} \mathrm{C}$ when compared to that of control. The increase in soil temperature due to solarization is lower than that reported by other researchers [26] [27]. This might be related to weather condition during solarization where the air
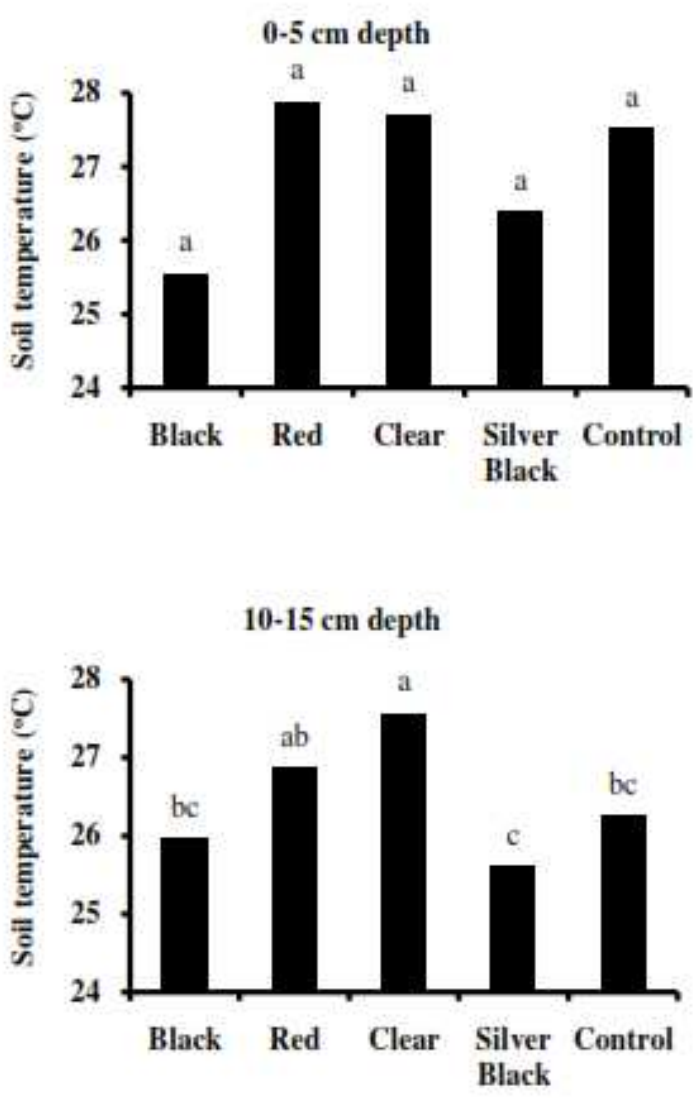

temperature was $24-28^{\circ} \mathrm{C}$ and during the experiment, the sky was cloudy most of the time. Another possibility is that it is required more time for solarization. The previous study by [19] indicated that soil solarization progressed effectively when it was the clear sky, no rain or cloud with sufficient time for solarization

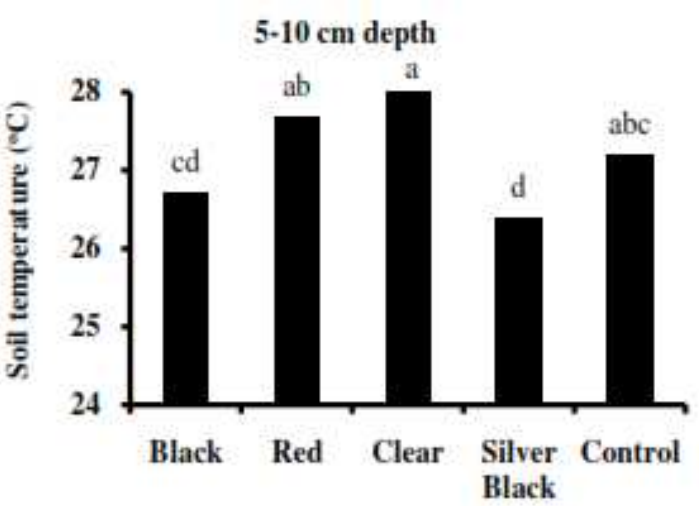

$15-20 \mathrm{~cm}$ depth

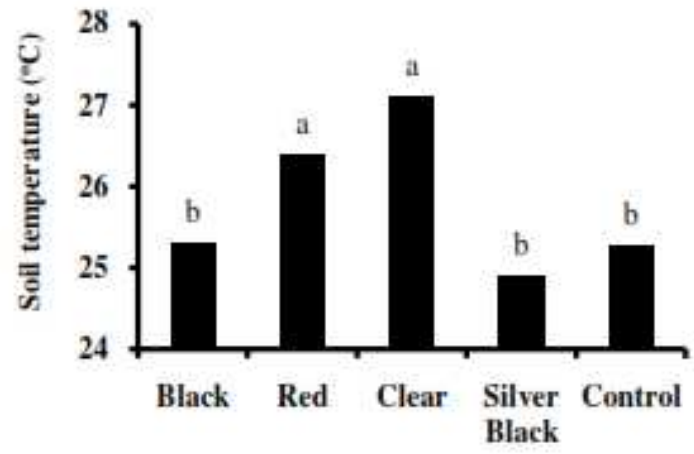

Trealment means with the same letter are not significantly different at DMRT 5\%

Fig. 1. Noon soil temperature at depth of 0-5, 5-10, 10-15, and 15-20 cm under mulch color treatment

The result of the experiment was also in agreement with that reported [28] which showed that transparent plastic mulch was more effective to raise soil temperature in comparison to that black plastic mulch. The increase of soil temperature, consequently, to suppress the growth of weed seeds in soil, even though soil temperature during the experiment was only between $21^{\circ} \mathrm{C}-25^{\circ} \mathrm{C}$. The effectiveness of soil solarization is highly dependent on weather of each season. In the summer when light intensity is high and no cloud, soil solarization for 4-6 weeks raised soil temperature up to $42^{\circ} \mathrm{C}$, influencing soil microorganism and weeds up to the depth of $10 \mathrm{~cm}$ from the soil surface [29].

Another study by [30] indicated that heat accumulation resulting from plastic mulch was higher than rice husk mulch as well as control (without mulch). Weed suppression due to increasing in soil temperature from soil solarization pronouncedly increased the yield of cucumber.
As indicated in Figure 2, soil solarization is effective to control weed at a soil depth of $0-15 \mathrm{~cm}$, not at the deeper depth of soil profile. One month of solarization is not sufficient to inhibit weed seed germination at lower depth possibly due to heat accumulation mainly at a shallower depth. The previous result pointed out that soil solarization suppressed weed growth at soil surface [31]. Mulch treatment reduces weed growth by $67.02-77.66 \%$ at $0-5 \mathrm{~cm}$ in comparison to that of control (without mulch). Highest suppression was obtained at red plastic mulch while the lowest reduction was treated with silver-black plastic mulch. A study conducted by [19] concluded that soil solarization was capable of declining weed growth up to 50-93\%, mainly due to an increase in soil temperature. At deeper soil layer $(5-10 \mathrm{~cm})$, lower reduction of weed growth suppression was observed (32.25-68.58\%); followed by deeper soil layer. This might be associated with lower soil temperature at the deeper soil surface. Earlier researchers revealed that as soil temperature increased, weed germination was reduced significantly [32] [33]. 


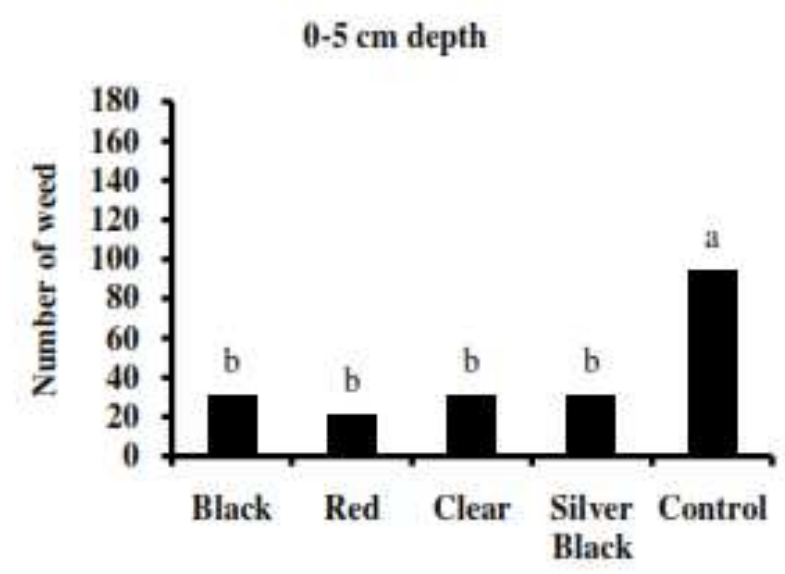

$10-15 \mathrm{~cm}$ depth

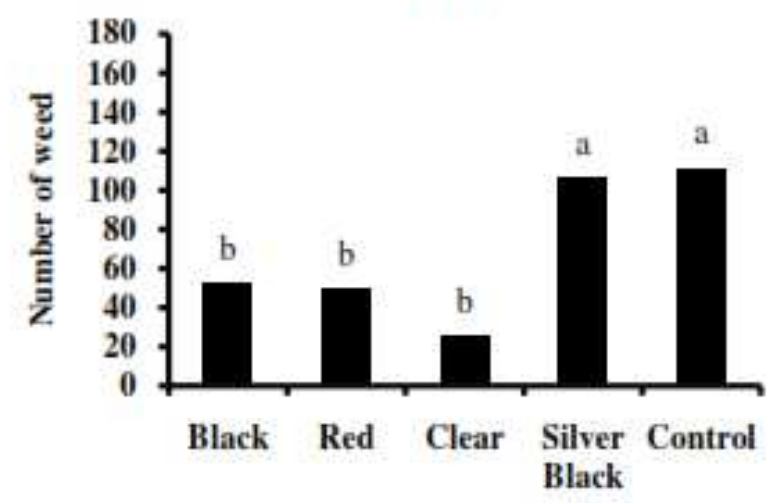

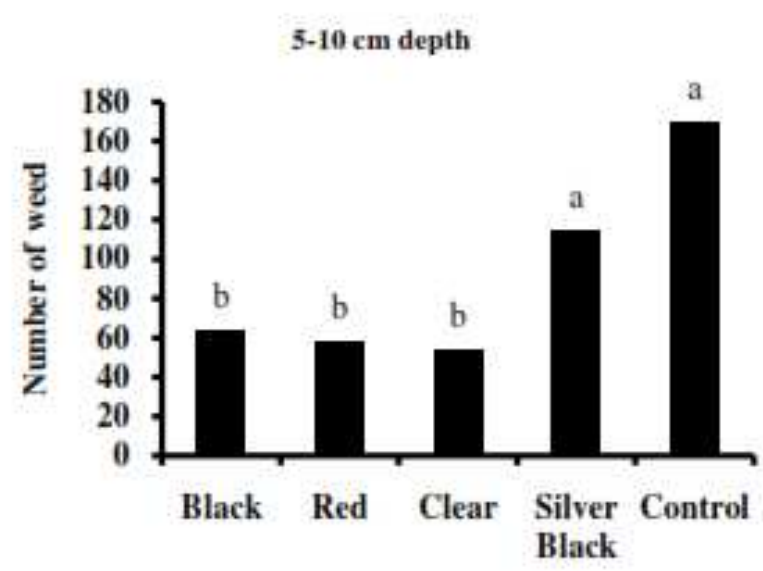

$15-20 \mathrm{~cm}$ depth

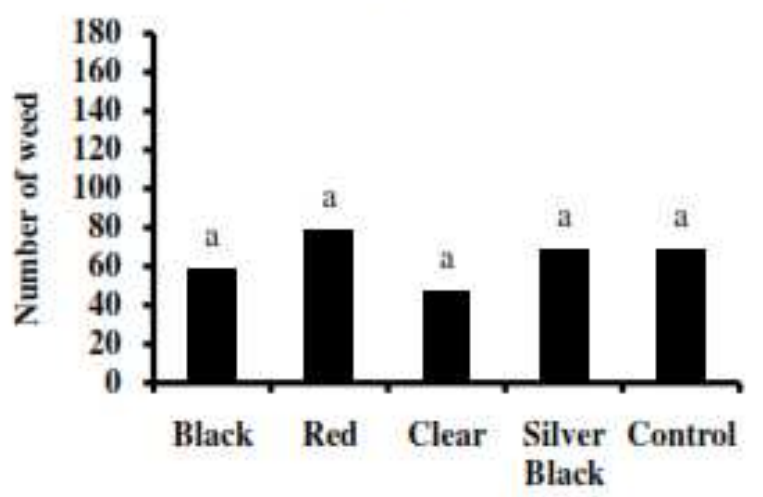

Treatment means with the same letter are not significantly different at DMRT 5\%

Fig. 2. Number of weed at different soil depth under different mulch color

An experiment conducted by [34] which testing 4 different mulches, i.e. EVA, LDPE, COEX, and BDP on lettuce confirmed that soil solarization was capable of suppressing the weed growth. However, a significant difference among types of mulches was not detected. In addition, BDF was not effective to control Common purslane and Common amaranth. Another research carried out by [35] found out that blue polythene provided the highest suppression of weed growth as indicated by lowest weed biomass. Solarization with blue polythene reduced weed biomass by $153 \%$.

Figure 2 also shows that at a soil depth of $5-15 \mathrm{~cm}$, soil solarization for a month using clear plastic mulch is more effective to reduce weed growth than another color of plastic mulch. The experiment carried out [28] also concluded that transparent plastic mulch was more effective to increase soil temperature than black plastic mulch. However, this result did not coincide with that suggested by [22] [23] where clear plastic mulch stimulated weed growth and increased weed population.

A study conducted by [28] indicated an inconsistent result of soil solarization effect on seed bank germination. Germinate of Ciperus scoparius was obtained higher in mowing treatment and control as compared to soil solarization treatment. The result showed that even though soil solarization was capable of reducing seed bank viability, the certain seeds still germinated, indicating that soil solarization did not suppress all weed seeds. Weeds such as Geranium carolinianum, Juncus sp., Daucus carota, Trifolium sp., Vicia sp., Cirsium sp., Hypericum perforatum, Plantago sp., dan Stellaria sp. were examples which still germinated after soil solarization.

This experiment indicates that certain weed species are susceptible but others resistant to soil solarization. An earlier study by [36] recommended using transparent polyethylene mulch amended with 30 ton $\mathrm{ha}^{-1}$ of animal manure in August - September to control soil burned fungi and weed species and to increase the yield of cabbage and eggplant.

As indicated in Figure 1 that clear plastic mulch increases soil temperature $0.54-1.84 \%$ higher than that of control, while black, red, and silver-black plastic mulches had lower soil temperature. This might cause more effective soil solarization using clear plastic mulch. 


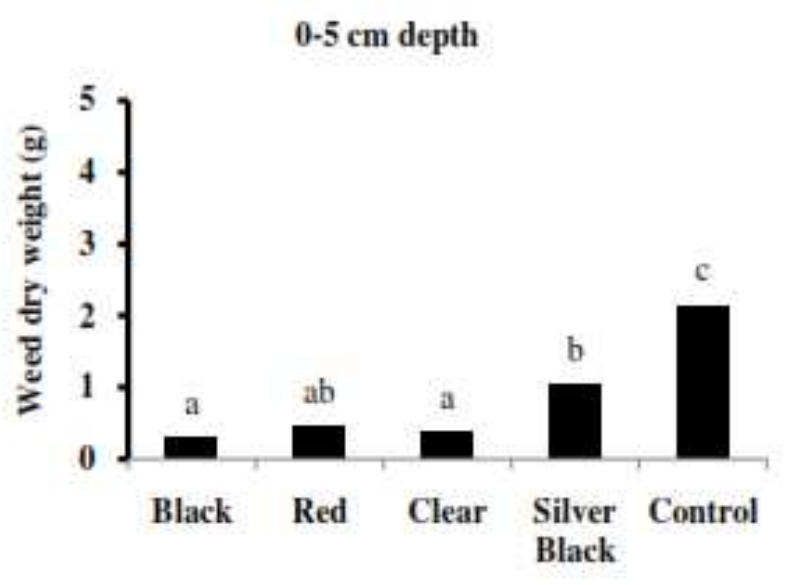

$10-15 \mathrm{~cm}$ depth

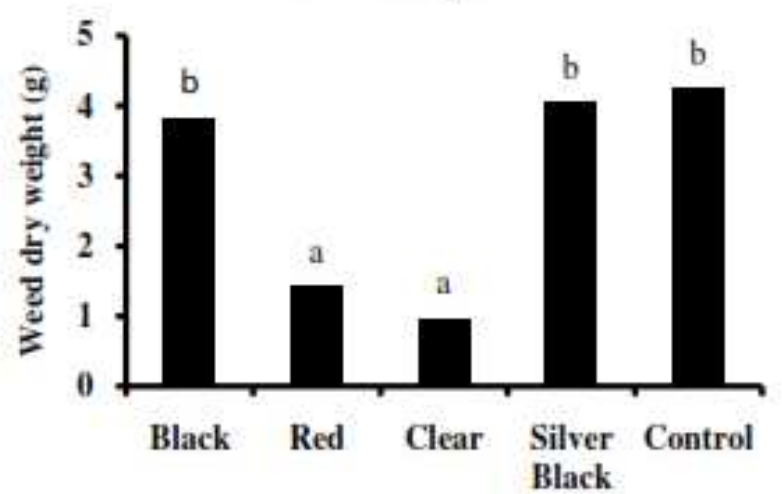

\section{$5 \cdot 10 \mathrm{~cm}$ depth}

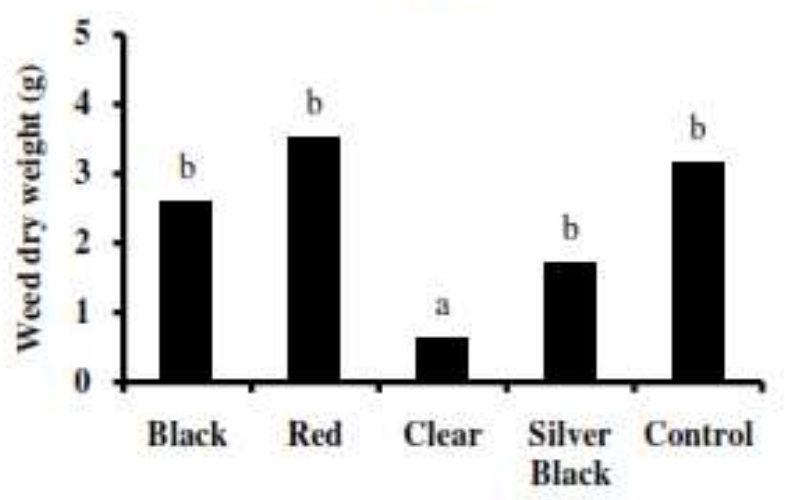

$15 \cdot 20 \mathrm{~cm}$ depth

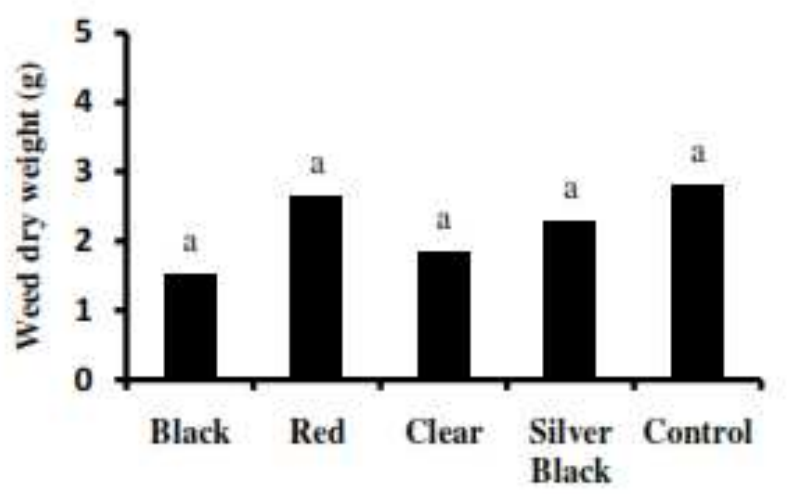

Treatment means with the same letter are not significantly different at DMRT 5\%

Fig. 3. Weed dry weight at different soil depth as affected by soil solarization using different mulch color

Treatment of clear plastic mulch for a month exhibited highest weed growth suppression as compared to other treatments, indicated by lowest weed dry matter, mainly at the soil depth of $0-15 \mathrm{~cm}$ (Figure 3.). This might be related to the effect of soil solarization using clear plastic mulch where soil temperature increased up to $0.54-1.32^{\circ} \mathrm{C}$ at the depth.

Even though plastic mulch was able to increase soil temperature, it was not able to suppress the germination and growth of weeds. During the experiment, average soil temperature ranged between $24^{\circ} \mathrm{C}-28^{\circ} \mathrm{C}$. This result coincided with that concluded by [37] which temperature affected weed seed germination. The optimum temperature for seeds of Silybum marianum dan Avena fatua to germinate was $25^{\circ} \mathrm{C}$. Above $\left(40^{\circ} \mathrm{C}\right)$ and below $\left(15^{\circ} \mathrm{C}\right)$ this temperature reduced germination of the two weed species. This indicates that temperature influences the establishment and the growth of S. marianum dan A. Fatua.

Another study by [38] showed that longer soil solarization resulted in lower weed seed bank, weed population, and weed dry weight. Soil solarization for 60 days was more effective in reducing weed population and dry weight than 50, 40,30, 20, and 10 days.

Solarization using clear plastic mulch is the most effective treatment to inhibit weed seed germination, indicated by the lowest number of weed growth and lowest weed dry matter.
A different result was reported by [39] where among different mulch color, transparent plastic mulch produced higher weed dry weight than black, silver black, as well as blue plastic mulches.

\section{CONCLUSIONS}

Soil solarization for a month using clear plastic mulch had the highest effect on soil temperature, increasing by 0.54 $1.84 \%$ as compared to control (without mulch). Treatment of plastic mulches was effective to suppress seed inhibition at a soil depth of $0-15 \mathrm{~cm}$, as indicated by numbers of weed germination and its dry matter. Longer soil solarization is necessary to obtain the highest reduction of weed growth in the tropical highland organic farming system.

\section{ACKNOWLEDGMENT}

Appreciation goes to Directorate General of Research and Extension, Ministry of Research, Technology and Higher Education for financing this project through 2016 Fundamental Research Scheme. Appreciation also goes to CAPS Research Station, Faculty of Agriculture, the University of Bengkulu for providing land and other necessary resources. 


\section{REFERENCES}

[1] Z. Muktamar, S.Y.K. Hasibuan, D. Suryati, and N. Setyowati, "Column study of nitrate downward movement and selected soil chemical properties' changes in mine spoiled soil as influenced by liquid organic fertilizer," J. Ag Tech. vol. 11, no. 8, pp. 2017-2027, 2015.

[2] Z. Muktamar, Fahrurrozi, Dwatmadji, N. Setyowati, S. Sudjatmiko, and M. Chozin, "Selected macronutrients' uptake by sweet corn under different rates of liquid organic fertilizer in closed agriculture system," IJASEIT., vol. 6, no. 2, pp. 258-261, 2016.

[3] N. Setyowati, Z. Muktamar, S. Oktiasa, and D. W. Ganefianti, "Growth and yield of chili pepper under different time application of wedelia (Wedelia trilobata) and siam weed (Chromolaena odorata) organic fertilizer," IJASEIT., vol. 4, no. 6, pp. 13-16, 2014

[4] N. Setyowati, Z. Muktamar, and I. Puspitasari, "Weed based organic fertilizer to reduce the application of synthetic fertilizer in mustard (Brassica sinensis L.)," Ag Tech., vol. 11, no. 8, pp. 1677-1683, 2015.

[5] Fahrurrozi, Z. Muktamar, Dwatmadji, N. Setyowati, S. Sudjatmiko, and M. Chozin, "Growth and yield responses of three sweet (Zea mays L. Var. Saccharata) varieties to local based organic fertilizer," IJASEIT., vol. 6, no. 3, pp. 319-323, 2016

[6] S. Utami, "Kemelimpahan jenis gulma tanaman wortel pada sistem pertanian organik," BIOMA., vol 11, no 2, pp. 54-58 (in Indonesian), 2009.

[7] W.P. Anderson, "Weed Science: Principles,". 2nd. ed. West Publishing Co. New York, 1983

[8] J. J. Stapleton, "Soil solarization in various agricultural production systems," Crop Protection, vol. 19, pp. 837-841, 2000.

[9] R. M. Dahlquist, T. S. Prather, and J. J. Stapleton, "Time and temperature requirements for weed seed thermal death," Weed Science, vol. 55, pp. 619-625, 2007.

[10] F.S. Moursy, F. A. Mostafa, and N. Y. Solieman, "Polyethylene and rice straw as soil mulching: Reflection of soil mulch type on soil temperature, soilborne diseases, plant growth and yield of tomato," Global Journal of Advanced Research, vol. 2, no. 10, pp. 1497-1519, 2015

[11] C.L. Elmore, J.J. Stapleton, C.E. Bell and J.E. Devay, "Soil solarization: A non-pesticidal method for controlling diseases, nematodes and weeds," Vegetable Research and Information Center. University of California, USA, 1977.

[12] I.A. Khan, Z. Ullah and I. Daur, "Comparison of different weed control techniques in maize," Global Journal of Science Frontier Research Agriculture and Veterinary, vol 13, no 4, pp. 13-15, 2013.

[13] A.K. Singh and S. Kamal, "Effect of black plastic mulch on soil temperature and tomato yield in mid hills of Garbwal Himalayas," Journal of Horticulture and Forestry, vol 4, no 4, pp. 78-80, 2012.

[14] F. Golzardi, Y. Vaziritabar, Y. Vaziritabar, S. Sarvaramini, and S. Z. Ebadi, "Solarization period and thickness of polyethylene sheet effects on weed density and biomass," Indian Journal of Fundamental and Applied Life Sciences, vol. 4, (S3), pp. 587-593, 2014.

[15] L. Ibarra-Jimenez, R.H. Lira-Saldivar, L.A. Valdez-Agnilar and J. Lozano-Del Rio, "Colored plastic mulches affect soil temperature and tuber production of potato," Acta Agriculturae Scandinavica, vol 61, no 4, 2011. [Online]. Available: http://www.tandfonline.com/doi/citedby/ 10.1080/09064710.2010.495724? scroll=top\&needAccess $=$ true

[16] W. Bond, R.J. Turner and A.C. Grundy. (2003) A Review of nonchemical weed management, HDRA. The Organic Organization. [Online]. Available: http://www.organicweeds.org.uk.

[17] J. Marquez and K. Wang. "Soil solarization as an organic preemergent weed management tactic," College of Tropical Agriculture and Human Resources, University of Hawaii at Manoa, 2014.

[18] P. Harsono, J. Soedarsono, Tohari dan D. Shiddieq, "Pengaruh macam mulsa terhadap sifat-sifat tanah vertisol," Jurnal Penelitian Teh dan Kina, vol 12, no 1-2, pp. 1-8 (in Indonesian), 2009.

[19] C.L. Elmore, "Effect of soil solarization on weeds," Department of Botany, University of California, Davis, USA, 2012
[20] G. Mauromicale, A. L.Monaco, A. M. G. Longo, and A. Restuccia, 'Soil Solarization, a non chemical method to control branched broomrape (Orobanche ramosa) and improve the yield of greenhouse tomato,"Weed Science, vol. 53, pp. 877-883, 2005.

[21] R. A. Marenco and D. C. Lustosa, "Soil solarization for weed control in carrot," Pesq. Agropec. Bras., vol.35, no.10, pp. 2025-2032, 2000.

[22] H.R. Rajablariani, F. Hassankhan and R. Rafezi, "Effect of colored plastic mulches on yield of tomato and weed biomass," International Journal of Environmental Science and Development, vol 3, no 6, pp. 590-593, 2012.

[23] M. Ashrafuzzaman, M.A. Halim, M.R. Ismail, S.M. Shahidullah and M.A. Hossain, "Effect of plastic mulch on growth and yield of chili (Capsicum annum L.)," Brazilian Archive of Biology and Technology, vol 54 no 2, pp. 321-330, 2011.

[24] M. Soerjani, A.J.G.H. Konstermarus and G. H. Tjitrosoepomo, "Weeds of Rice in Indonesia," Balai Pustaka, Jakarta, (in Indonesian), 1980.

[25] M. A. Kuva, P. L. Alves, and E. L. A. Erasmo, "The effects of solarization with transparent plastic on purple nutsedge (Cyperus rotundus)," Planta Daninha, vol. 13, no. 1, pp. 26-31, 1994.

[26] Arora and N. T. Yaduraj, "High-temperature effects on germination and viability of weed seeds in soil," J. Agron. and Crop Sci., vol. 181, no. 1 , pp. 35-43, 1998.

[27] M. A. Khan, K. B. Marwat, A. Amin, A. Nawaz, R. Khan, H. Khan, and H. U. Shah, "Soil Solarization: An organic weed-management approach in cauliflower," Communications in Soil Science and Plant Analysis, vol. 43, pp. 1847-1860, 2012.

[28] A. H. Fraser, 'Use of solarization to kill the root crown and reduce the seed bank viability of Rubus armeniacus Focke and Cytisus scoparius (L) Link, MSc. Thesis. School of Environmental and Forestry Science. University of Washington, 2013.

[29] A. Gamliel and J. Katan, "Soil Solarization: Theory and Practice," American Phytopathological Society, St. Paul, MS, 2012

[30] T. J. Homez and H. Arouiee, "Evaluation of soil temperature under mulches and garlic extract on yield of cucumber (Cucumis sativus L.) in greenhouse condition," Journal of Horticulture, vol. 3, no. 1, pp. 15, 2016.

[31] R. Mandumbu, C. Karavina and T. Muoni, "Effect of temperature, residue level and burial depth on germination of two weed: Implication to conservation agriculture," in African Crop Science Conference Proceedings, vol.11, pp. 97-100, 2013.

[32] G. H. Egley, "High-temperature effects on germination and survival of weed seed in soil," Weed Science, vol. 38, no. 4/5, pp. 429-435, 1990.

[33] T. M. Webster, "High temperatures and durations of exposure nutsedge (Cyperus spp) tuber viability",Weed Science, vol. 51, no. 6, pp. 1010-1015, 2003.

[34] V. Candido, T. D. Addabbo, V. Miccolis, and D. Castronuovo, "Effect of different solarizing materials on weed suppression and lettuce response," Phytoparasitica, vol. 40, pp. 185-194. 2012.

[35] M. Pramanick, D. Pal, A. Roy, S. Debnath and A. Dwary, "Effect of polythene mulches on weed management in onion," Journal of Crop and Weed, vol.2, no. 1, pp. 20-22, 2006.

[36] B. T. Hamooh and S. G. Alsolaimani, "Soil solarization timing effects on yield of cabbage (Brassica olera) and eggplant (Solanum melongena 1.) and as a weed control," Australian Journal of Basic and Applied Sciences, vol. 8, no. 3, pp. 307-312, 2014

[37] S. Kashmir, M. A. Khan, A. A. Shad, K. B. Marwat, and H. Khan, "Temperature and salinity affect the germination and growth of Silybum marianum Gaerth and Avena fatua L.," Pak. J. Botani, vol. 48, no. 2, pp. 469-476, 2016.

[38] M. R. Talibi and A. R. Golparvar, "Survey effect of solarization duration and thickness of polyethylene plastic sheets on the characteristics and seed bank of weeds," Scientia Agriculture, vol. 2, no. 2, pp. 26-32, 2013

[39] H. R. Rajablairiani, M. Sheykhmohamady, and M. AghaAlikhami, "Growth of sweet corn and weeds in response to colored plastic mulches," Journal of Advanced Agricultural Technologies, vol. 2, no. 1, pp. 42-45, 2015. 